\title{
Amerikan Çokkültürlülüğünü Yeniden Düşünmek: Hispanik/Latinolar ve Amerikan Toplumu İçerisindeki Rolü
}

\author{
Orhan Çifçiं
}

\section{Öz}

Bu makale Amerikan çokkültürlülüğü özelinde Hispanik/Latino azınlığının ülke içerisindeki koşul ve konumlarını inceleme hedefi gütmektedir. Bağımsızlığının ilanı ve uluslararası politikada ulus-devlet olarak tanınmasının ardından ABD, farklı bölgelerden aldığı göç dalgaları neticesinde çokkültürlü bir toplum yapısına bürünmüştür. Ülke içerisinde din, dil, ırk ve etnik çeşitliliklere bağlı olarak oluşan çokkültürlü yapıda Beyaz Amerikanlar çoğunluğu oluşturmasına rağmen günümüzde sayıca en büyük azınlık grubu olan Hispanik/Latinoların orta ve uzun vadede farklı alanlarda görünürlüğünün büyük oranda artması beklenmektedir. Bu doğrultuda çalışmada Amerikan toplumunda Hispanik/Latinoların siyasi, ekonomik ve eğitim alanlarındaki konumu irdelenmiş ve çokkültürlü yapı içerisinde nasıl bir etki doğurduğu ele alınmıştır.

Anahtar Kelimeler: Çokkültürlülük, Amerikan Çokkültürlülüğü, Hispanik/Latino, Siyaset, Ekonomi, Eğitim.

Rethinking American Multiculturalism: Hispanic/Latinos and Their Role in the American Society

\section{Abstract}

This article seeks to examine the conditions and status of Hispanic/Latinos in American cultural diversity. The U.S. has wrapped in a diverse societal structure along with migration waves from various regions after its declaration of independence and being recognized as a nation-state in international system. Within this multicultural structure based on religion, race and etnicity, visibility of Hispanic/Latinos in the society, as the largest minority group in the country, is expected to increase considerably in the future. In that respect, the study analyses political, economic and educational conditions of Hispanic/Latinos and their mounting impact in these particular areas.

Keywords: Multiculturalism, The U.S. multiculturalism, Hispanic/Latinos, Politics, Economy, Education.

*Doktora Öğrencisi | Polis Akademisi Güvenlik Bilimleri Enstitüsü | orhan.cifci93@gmail.com ORCID: 0000-0002-5746-4258 | DOI: 10.36484/liberal.815972

Liberal Düşünce Dergisi, Yıl: 25, Sayı: 100, Güz 2020, ss. 91-114.

Gönderim Tarihi: 25 Ekim 2020 | Kabul Tarihi: 25 Aralık 2020 


\section{Giriş}

Bağımsızlığından günümüze kadar geçen süreç içerisinde $A B D$, dünyanın farklı bölgelerinden aldığı göçlerle birlikte çokkültürlü bir sosyolojik yapıya sahip olmuştur. Söz konusu göçlerin büyük bir kısmı bilhassa 18.yy sonu ve 19.yy'ın başları itibariyle Avrupa'nın farklı ülkelerinden başlamış daha sonrasında ise Rusya, Asya ve Latin Amerika gibi diğer farklı coğrafyalardan ABD’ye büyük bir göç akışı gerçekleşmiştir. Günümüzde de halihazırda ülkeye devam eden göç dalgaları ABD’nin mevcut toplumsal yapısını şekillendiren başlıca etkiye sahip olmuştur. Tarihsel süreç boyunca gerçekleşen tüm bu göç hareketleri ABD toplum yapısını şekillendiren temel dinamik olarak belirirken ülke bütünüyle dini, etnik ve mezhepsel farklılıklar temeli üzerine oturan çokkültürlü bir yapı karakteristiğine bürünmüştür. Öyle ki, neredeyse bütünüyle göçmen hareketleri sonucu ortaya çıkan Amerikan kimliği ve toplum yapısı ülkenin, ABD eski başkanı John F. Kennedy tarafından Göçmen Ulusu (A Nation of Immigrants) olarak isimlendirilmesinin önünü açmıştır (Kennedy, 1964; Huntington, 2004). Bu argümana karşı bir şekilde siyaset bilimci Samuel Huntington ise tek bir Amerikan kimliği olgusu üzerinde 1srarla durmuş, Amerikan toplumunun göçmenlerden oluşan bir ulus olarak nitelendirilmesinin sığ bir yaklaşım olduğunu ileri sürerken bu toplumun Yerleşimciler (Settlers) olarak isimlendirilen İngiliz gruplar tarafından oluşturulduğunun altını çizmiştir. Dolayısıyla Huntington'a göre modern Amerikan toplumunun kökleri göçmenler tarafından değil yerleşimciler tarafından oluşmuştur. Tüm bu tartışmalar geçmişten günümüze akademik alanda yoğun bir şekilde tartışılmaya devam ederken, ortaya çıkan çeşitlilik durumunun yapısı zaman içerisinde ABD içerisindeki farklı grupların siyasi, ekonomik, sosyal ve diğer tüm alanlardaki artan talepler doğrultusunda ülke içerisindeki konumları ve temsiliyet alanlarını yeniden belirlemiştir.

ABD'de günümüzde yaklaşık olarak yüzde 60'lık bir oranla WASP (White Anglo-Saxon Protestant) olarak adlandırılan Beyaz Amerikanlar ülkenin nicel anlamda hâkim çoğunluğunu oluşturmaktadır. Beyaz Amerikanlar ABD’nin toplumsal yapısı içerisinde sayıca büyük bir çoğunluğu meydana getirmesine rağmen ülke içerisinde azınlık olarak nitelendirilen ve ilerleyen dönemlerde nüfuslarının yanı sıra siyasi, ekonomik ve sosyal etkilerinin önemli ölçüde artacağı tahmin edilen gruplar bulunmaktadır. Hispanik/Latinolar, Beyaz Amerikanların ardından yaklaşık olarak yüzde 18.5 gibi bir oranla ABD içerisindeki en büyük azınlık grubunu oluşturmaktadır. Afro/Amerikanlar (Siyahiler), Asyalılar ve Amerikan Yerlileri (Indian Natives) ise ABD içerisindeki diğer azınlıklardır (US Census Bureau, 2019). 
Bu çalışma, ABD’nin sahip olduğu çokkültürlü toplum yapısı içerisinde azınlık olarak nitelendirilen Hispanik/Latinoların ülke içerisindeki farklı temsiliyet alanlarını analiz etme hedefi gütmektedir. Çalışmada Hispanik/Latinoların ele alınmasının başlıca nedeni günümüzde ABD içerisinde niceliksel olarak en büyük azınlığı oluşturmalarının yanı sıra, orta ve uzun vadede olmak üzere, gelecek dönemlerde ülkenin toplam nüfus oranında en hızlı artışa sahip olan grup olarak öne çıkmasıdır. Yine benzer bir şekilde, çalışmada Hispanik/Latinoların değerlendirilmesinin diğer bir önemli nedeni azınlığın niteliksel olarak da ABD içerisinde görünürlüğünün artmasıdır. Özellikle son dönemlerde $\mathrm{ABD}$ içerisinde azınlığın siyasi ve ekonomik düzeyde rolünün somutlaşması, Hispanik/Latinoların özellikle çokkültürlülük düzeyinde daha derin bir şekilde tartışılması ve yeniden değerlendirilmesi gerekliliğini doğurmuştur. Günümüzde 328 milyon nüfusa sahip ABD içerisinde Hispanik/ Latino nüfusunun 60 milyona ulaşması ve azınlık üyelerinin özellikle yüksek öğrenim düzeyinde olmak üzere eğitim seviyelerinde hızlı bir ivmelenmenin bulunması farklı alanlarda taleplerinin de daha görünür bir konuma evrilmesine neden olmuştur. Öte yandan, çalışmada Hispanik/Latinoların merkeze konulmasının diğer bir nedeni bazı entelektüel çevrelerce Hispanik/Latino kimliğinin tek bir Amerikan kimliğine en büyük tehdidi oluşturması ve Amerikan kimliğinin Hispanikleşmesinin ileri sürülmesidir (Huntington, 2004). Bu minvalde çalışma ilk olarak çokkültürlülük temeline oturtulan teorik ve felsefi yaklaşımları tartacaktır. Çalışmanın ampirik boyutu özelinde ise takip eden bölümlerde, $\mathrm{ABD}$ içerisinde kronik bir boyut kazanmış olan ve son dönemlerde de "Siyahi Hayatı Değerlidir" (Black Lives Matter) hareketi neticesinde yeniden ülkenin başlıca gündemi arasına yerleşen azınlık problemi, Hispanik/Latino vakası özelinde değerlendirilecek ve günümüzde ABD içerisindeki siyasi, ekonomik ve eğitim koşulları ele alınacaktır.

\section{Çokkültürlülük Üzerine Felsefi ve Teorik Yaklaşımlar}

Literatür çokkültürlülük kavramı üzerine kapsamlı ve derinlemesine bir tartışma yürütmektedir. Ortaya çıkan tartışmalar neticesinde çokkültürlülüğün kavramsal boyutu üzerine büyük bir literatür oluşmuştur. Bahse konu tartışmaların özellikle son dönem itibariyle daha fazla yoğunlaşmasında küreselleşmenin, devlet içi düzeyde çeşitli etnik yapı ve dini aidiyete bağlı grupların taleplerini daha görünür bir yapıya sokması etkili olmuştur (Çolak, 2010: 6-7). Çokkültürlülük en genel anlamıyla analiz edildiğinde farklı gelenek, davranış, adet, dil ve/veya dine sahip birey ya da toplumların aynı sosyolojik yapı içerisinde yaşaması olarak kavramsallaştırılmaktadır. Bu minvalde değerlendirildiğinde çokkültürlülük kavramı kimlik ya da tanınma politikası 
kavramlarıyla da ilişkili olarak ele alınmaktadır (Colombo, 2014: 1). Devlet içerisinde bulunan farklı birey veya grupların siyasi, ekonomik ya da diğer farklı alanlardaki temsiliyet veya tanınma talebi üzerine çokkültürlülük devlet politikaları özelinde başlıca gündem olarak öne çıkmıştır. Bu durum söz konusu bireylerin ve grupların ülke içerisinde yalnızca isteklerinin karşılanması anlamında değil ayrıca toplum içerisinde ayrı bir kimlik olarak tanınma talepleri neticesinde de şekillenmiştir (Kukathas, 1998: 686). Benzer bir şekilde, çokkültürlülük kavramının literatürde birey ve bireyin toplum içerisindeki rolüne vurgu yapılarak ele alınması kavramın liberal teoriyle bağlantılı olarak değerlendirilmesi ve liberal demokrasinin çokkültürlülüğe zemin hazırladığı fikrinin genel kabulüne olanak sağlamıştır (Modood, 2007: 7).

Çokkültürlülük üzerine oluşturulan birçok çalışma kavram üzerine farklı tartışmaları da beraberinde getirmiştir. Dolayısıyla çokkültürlülüğün kavramsallaştırması üzerine genel bir görüş birliği sağlanamamıştır. Kavramın tanımlanmasına yönelik literatürdeki en önemli çalışmalardan birisi Bhikhu Parekh tarafından yazılmıştır. Parekh Rethinking Multiculturalism: Cultural Diversity and Political Theory isimli çalışmasında çokkültürlüğünün farklı yapıları üzerinde durmuş ve başlıca üç unsuru bu bağlamda değerlendirmeye sokmuştur. Bu yapılardan birincisine göre Parekh, bir toplum içerisindeki bireyler ortak bir kültürel geçmişe sahip olsa da azınlık olarak nitelendirilebilecek grupların çoğunluğun sahip olduğu pratiklerle kıyaslandığında farklı uygulamalara sahip olabileceğini ileri sürmektedir. Parekh tarafından öne sürülen diğer bir varsayım ise toplum içerisindeki azınlık üyelerinin pratikte yaygın olarak başvurulan davranış ya da geleneklere eleştirel bir yaklaşımla karşı çıkabileceğini vurgulamaktadır. Parekh'in son tezi ise günümüz yapısı içerisindeki modern toplum dinamiklerini ele almaktadır. Buna göre günümüz toplumlarında farklı yaşam biçimleri ve pratiklere sahip farklı gruplar birlikte iç içe yaşamaktadır. Parekh'e göre sözü geçen bu yapılardan en az birinin herhangi bir toplum yapısı içerisinde bulunması o toplumu çokkültürlü ya da kültürel çeşitlilik temeline oturan bir yapıya sokmaktadır (Parekh, 2000: 1-5).

Parekh'in varsayımlarına paralel bir şekilde Will Kymlicka da çokkültürlülüğü toplumlar içerisindeki farklı kültür ya da geleneklerin bir arada bulunduğu sosyolojik bir yapı olarak tanımlamaktadır (Kymlicka, 1995: 10). Bu düzeyde, Kmylicka çokkültürlülük kavramsallaştırmasını devlet içi düzeyde farklı yapılara sahip grupların tanınması olarak yapmaktadır (Colombo, 2014: 1). Kmylicka kavramı "kültürel çeşitlilik" temelinde ele almakta ve iki farklı yaklaşım ileri sürmektedir. Bu yaklaşımlardan birincisi devlet içerisindeki azınlıkların çoğunluğun sahip olduğu yaygın kültürden 
kendilerini ayrı tuttuğunu ve kendilerini çoğunluktan ayrı bir toplum olarak tanımladığını varsaymaktadır. Kmylicka'nın ikinci varsayımı ise birey temeline oturmaktadır. Birey özelinde bilhassa göçmenler üzerinde duran Kmylicka, göçmenlerin kendilerini çoğunluk grubunun içerisine entegre etme motivasyonuyla hareket ettiğini ve kültürel çeşitlilik üzerine oturan yapıya dahil olmaya çalıştıklarının altını çizmektedir (Kymlicka, 1995: 10-11).

Joseph Raz (Raz, 1998) ve John Rawls (Rawls, 1985) da Kmylicka'ya benzer bir şekilde çokkültürlülük açıklamalarını liberalizm temeline oturturken, literatürdeki diğer farklı hakim yaklaşımlar liberalizm ve çokkültürlülük arasındaki ilişkilendirmeye yönelik eleştirel bir bakış açısı yöneltmektedir. $\mathrm{Bu}$ eleştiriler yaklaşımlardan biri Tariq Modood’a aittir. Modood çokkültürlülük ve liberal demokrasi arasında bir bağlantı olduğunu ileri sürmesine rağmen bu olgunun yalnızca liberal demokrasinin bir sonucu olduğu şeklinde oluşturulan varsayımlara da karşı çıkmaktadır. Dolayısıyla Modood, çokkültürlü yapının liberal norm ya da ilkelerle doğrudan ilişkili olduğunu kabullenmesine rağmen söz konusu kültürel çeşitliliğin kendisinin liberalizme karşı bir meydan okuma olarak ortaya çıkabileceğini de belirtmektedir (Modood, 2007: 7; Modood, 2001: 246).

Literatürdeki diğer bir farklı yaklaşım Charles Taylor tarafından ortaya atılmıştır. Taylor çokkültürlülük yaklaşımını tanınma politikası özelinde değerlendirirken, kavramı toplumun sahip olduğu azınlıklar veya devlet içerisindeki diğer alt grupların çeşitli düzeylerde tanınma talebi olarak ele almıştır (Taylor, 1994: 25). Bu bağlamda Taylor, kimlik kavramını ve tanınma politikasını birlikte incelemekte ve farklı aidiyete sahip bireylerin tanınmasının onların kimliklerini yeniden şekillendirmede başlıca faktör olduğunu belirtmektedir. Buna rağmen Taylor, toplum içerisinde farklı azınlıkların ya da gruplarının tanınmasının o toplum için bir tehdit oluşturabileceğini ve istikrarsızlığa itebileceğini de tartışmaktadır (Taylor, 1994: 25). Çokkültürlülüğün felsefi ve pratik boyutu kapsamında literatürde diğer bir önemli tartışma konusu müdahale etmeme yaklaşımı sınırları içerisinde ortaya çıkmaktadır. Konuyu kimlik siyaseti özelinde ele alan Nafiz Tok, yapısal olarak birbirlerinden ayrışan farklı gruplar içerisindeki çeşitli fikirsel ve siyasi görüşler üzerinden bir tanımlama yapmaktadır. Bu minvalde, meseleyi müdahale etmeme ya da ayrımcılık yapmama yaklaşımları üzerinden inceleyen Tok, bahse konu bu yaklaşımların çokkültürlülük ve sonuçlarına pratik bir çözüm bulamadığını iddia etmektedir (Tok, 2005: 43). 


\section{Amerikan Çokkültürlülüğüne Yönelik Kavramsal Yaklaşımlar}

ABD içerisindeki çokkültürlü toplum yapısı ve Amerikan yönetimleri tarafından ülkenin kültürel çeşitliliğine yönelik belirlenen politika yapım süreci ülkenin kuruluş aşamasından beri yoğun bir şekilde tartışılmaktadır. Ülkenin neredeyse bütünüyle farklı aidiyete sahip grup ve bireylerden oluşması, ABD içerisinde karar alıcıların ülkenin sahip olduğu sosyolojik yapıyı hassas bir düzlemde ele almasına neden olmaktadır. Yukarıda da değinildiği gibi çokkültürlülük üzerine literatürde farklı yaklaşımların bulunması Amerikan çokkültürlülüğünün ele alınmasında da farklı yorumlamaları ve eleştirileri beraberinde getirmektedir. Tüm bu farklı yaklaşımlar içerisinde ABD toplum yapısının sahip olduğu çokkültürlülük genel bağlamda iki farklı hakim yaklaşım tarafından tartışılmaktadır. Bu yaklaşımlardan birincisi olan Eritme Potası (Melting Pot) yaklaşımına göre ABD içerisinde farklı geçmiş ve aidiyete sahip etnik azınlıkların Amerikan yönetimleri tarafından tek tip bir yapı içerisine sokulmasına yönelik politikalar belirlendiği ve bu azınlıkların tek bir Amerikan kimliği içerisine oturtulmaya çalışıldığını ileri sürmektedir. Bu yaklaşımın tersi Salata Kasesi (Salad Bowl) ise ABD içerisinde azınlıkların sahip oldukları değer, aidiyet ya da kültürlere müdahil olunmadığı ve bunların kendi yaşam biçimlerini sürdürdüğünü ileri sürmektedir. Eritme potası pragmatik bir düzlemde tanımlamakta ve asimilasyon yaklaşımı ile benzer kullanılmaktadır. Eritme potası yaklaşımı etnik, dini ve ırksal çeşitlilik temeline oturan kültürel çeşitliliğin ülkenin toplumsal istikrar ve düzenine yönelik önemli bir tehdit durumu teşkil ettiğini ve çeşitliliğin daha da derinleşmesinin önüne geçilmesi gerektiğini ileri sürmektedir. Bu yaklaşım, çeşitliliğin derinleşmesinin toplumu ve bütünüyle ülkeyi bölünmeye götürecek bir süreci başlatabileceğinin üzerinde durmaktadır. Dolayısıyla eritme potası yaklaşımına göre ABD içerisindeki farklı aidiyetler tek bir Amerikan kimliği oluşturulması temeline oturtulmalıdır (Bond, 2002: 59-60).

Akademik literatür eritme potası yaklaşımını yoğun bir şekilde tartışmasına rağmen kavramın tanımlanmasına yönelik bir konsensus sağlanamamıştır. Buna rağmen Amerikan toplumunun kimliği hakkında idealist bir yaklaşım sunmaktadır. Yaklaşımın kökenleri yirminci yüzyılın başlarına dayanırken kavram ilk olarak 1910 yılında Chicago okulu tarafından ileri sürülmüştür. (Cazessus, 2008: 2).

ABD içerisindeki çokkültürlülüğün yorumlanmasında eritme potası yaklaşımı da kendi içerisinde ayrışmalar içermektedir. Bu ayrışmalardan en fazla öne çıkan yaklaşımlardan biri ise Anglo-Sakson uyum yaklaşımıdır. Bu yorumlama Anglo-Sakson kültürel ve aidiyet yapısının Amerikan 
çokkültürlülüğünün özünde olduğunu ve ülke içerisindeki diğer azınlık kültür ve gelenekleri üzerinde hâkim konumda bulunduğunu ileri sürmektedir. Bu model tek bir Amerikan kimliğinin önemi üzerinde dururken farklı geleneksel geçmiş ve aidiyete sahip birey ve grupların kendi yaşam biçimlerini bir kenara birakarak Anglo-Sakson modele uyum sağlamaları gerektiği yaklaşımını savunmaktadır (Orosco, 2016: 13-16).

Kökenlerini Alman ve İngiliz gelenek ve kültürlerinin oluşturduğu Anglo-Sakson model, günümüzde Amerikan çokkültürlüğünün açıklanmasında en fazla üzerinde durulan yaklaşımdır Literatürde başta Samuel Huntington ve Patrick Buchanan, Anglo-Sakson modelin Amerikan çokkültürlülüğünde pratikte uygulanması gerektiğini en fazla savunan iki akademisyen olarak öne çıkmaktadır. Huntington ve Buchanan, Anglo-Sakson modelin ABD’nin siyasi, ekonomik, sosyal ve kültürel bağlamda özünü meydana getirdiğinin altını çizmektedir (Orosco, 2016: 13-16). Başta Huntington, Anglo-Sakson tezini savunurken, Amerikan kimliğinin özellikle 1960’lı yıllardan itibaren bir bozulma süreci içerisine girdiğini ileri sürmüş ve bu durumu belli nedenlere bağlamıştır. Huntington'a göre bozulmanın en önemli nedeni bahse konu süreç içerisinde küreselleşmenin ekonomik boyutunun ön plana çıkması ve ulus altı kimliklerin küresel düzeyde sayısının artması olmuştur. Huntington'un ileri sürdüğü diğer bir neden ise ırk ve etnisite yaklaşım ve tanımlamalarında farklılıkların ortaya çıkması olmuştur (Huntington, 2004).

Eritme potası özelinde sunulan diğer bir başat tez kaynaşma modelidir. Kaynaşma modeli Amerikan toplumunun sahip olduğu kimliğin tek bir yapı içerisinde değerlendirilmemesi gerektiği ve sürekli değişim durumunda olduğunu ileri sürmektedir. Bahse konu yaklaşım ABD'ye gelen birey ya da toplumların ülke içerisindeki yerleşik hâkim kültüre asimile olduğunu ve bu durumun onları kendi aidiyetlerinden vazgeçme durumunda bıraktığını söylemektedir. Kaynaşma modeli Robert Park ve E.W. Burgess tarafından ortaya konmuştur (Orosco, 2016: 16-18).

Eritme potasına karşıt görüş Salata kâsesi ya da kültürel mozaik olarak tanımlanan, ülke içerisinde azınlık konumunda bulunan toplumların sahip olduğu nitelik ve kültürel aidiyeti kaybetmediğini ve baskın kültürle birlikte yaşam biçimini sürdürdüğünü belirtmektedir. Buna göre farklı kültürlerin tek bir yapı içerisine sokulmaya çalışılmadığı ve kültürel düzeyde homojen bir toplumun halihazırda yaratılmadığı düşünülmektedir. Dolayısıyla bu yaklaşım ABD içerisinde azınlık niteliğindeki toplumların bir taraftan kendi yaşam biçimlerini sürdürürken aynı zamanda kendi geleneklerinden de vazgeçmediğini ileri sürmektedir. Bu doğrultuda ülkenin farklı kültürlerin birleşimi 
sonucunda oluşturduğu yapı bir zenginlik olarak ele alınmakta ve kültürel çeşitliliğin devamlılığının sağlanması için bir kültürel koruma sağlanması gerektiğini ileri sürmektedir (Mahfouz, 2013: 2).

\section{Çokkültürlülük Özelinde Amerikan Toplumunun Özellikleri}

Amerika ana kıtasının keşfinin ardından bölgeye belli oranda göç hareketleri başlamasına rağmen 1776 yılında ABD’nin bağımsızlığını elde etmesi ve 1783 yılında uluslararası sistemde egemen bir devlet olarak tanınmasının ardından ülkeye dünyanın farklı bölgelerinden hızlı bir göçmen akışı başlamiştır. Bu koşullar ve göç dalgaları, ABD’nin kültürel çeşitliliğe erişmesinde itici güç olmuştur (Vialet, 1980: 4). Tarihsel bağlamda ele alındığında ABD içerisindeki bireylerin kabaca tamamı başka ülke doğumlu (Foreign Born) göçmenlerden ya da ülkenin bağımsızlık tarihine dayanan ve bu dönemde ülkeye gelen göçmenlerin soyundan meydana gelmektedir (Denhart, 2015: 20). ABD'deki çokkültürlü yapının oluşmasındaki asıl faktör olan göçmen dalgalarının ilki 19.yy'ın ortalarına dayanmaktadır. 1840-1880 döneminde gerçekleşen ve Birinci Büyük Göçmen Dalgası olarak betimlenen göçmen hareketiyle birlikte ABD’nin mevcut sosyolojik yapısının temelleri atılmıştır. Bahsi geçen bu göç hareketiyle birlikte 5 milyona yakın göçmen farklı motivasyonlarla ABD’ye geçiş yapmıştır. Bu göç dalgasını diğerlerinden ayıran başlıca özelliği ise çoğunluğunun Avrupa ülkelerinden gelmiş olmasıdır. Bu ülkeler arasında özellikle İngiltere, Almanya ve bazı İskandinavya ülkeleri başı çekmektedir (Passel, 1994: 19).

İkinci büyük göç dalgası ise 20.yy başlamasını takiben kendisini göstermiştir. Özellikle 1910'lu yıllarda çoğunluğunu İtalyanlar ve Avrupa'da ikamet eden Yahudilerin oluşturduğu yaklaşık 10 milyon göçmen ABD’ye yerleşmiştir. 20.yy'da başlayan bu göç hareketi özellikle 1930 ve 1940’larda başta Büyük Buhran ve II. Dünya Savaşı'yla önemli bir duraksama sürecine girmesine rağmen göç hareketleri belli bir düzeyde devam etmiştir (Passel, 1994: 19). 1965 sonrasında ise ABD’ye gerçekleşen göçler gerek yapısal gerekse motivasyon anlamında büyük farklılıkları içerisinde barındırmaktadır. Bu göç özelinde dünya nüfusunun da artışına bağlı olarak niceliksel anlamda büyük bir artış görülmüştür. Önceki dönemlerde ABD’ye gerçekleştirilen göçlerin büyük bir çoğunluğu Avrupa ülkelerinden gerçekleşse de bu dönem itibariyle özellikle dil ve din çeşitliliğinin daha da keskinleşmesine neden olmuştur (Hirschman, 2014: 71).

1965 sonrası dönemde ABD’ye göç eden hâkim grubu büyük oranda Asyalılar ve Latin Amerikalılar oluşturmuştur. Bu süreçte $A B D$ en fazla göçü 
bir Latin Amerika ülkesi olan Meksika'dan almıştır. Tüm göç hareketleri içerisinde yalnızca Meksikalılar \%30 gibi büyük bir oranı tek başına oluşturmuş ve yaklaşık olarak 11 milyon Meksikalı ABD’nin başta güney eyaletleri olmak üzere ülkenin farklı bölgelerine yerleşmiştir. Göç hareketinin \%20’lik diğer bir büyük bölümü ise farklı Latin Amerika ülkelerinden gerçekleşmiştir (Hirschman, 2014: 71-72). 19. yy itibariyle başlayan göç hareketleri sayısal ve niteliksel olarak ABD içerisinde büyük bir çeşitlilik yaratmasına rağmen 1980'li yıllarda başlayan son büyük göç dalgası ABD içerisindeki en büyük etkiyi yaratmıştır. Bir öncekinde olduğu gibi buradaki göçmenlerin de büyük çoğunluğunu Latin Amerika ülkeleri oluşturmuştur (Passel, 1994: 20). Tüm bu aralıklı büyük göç dalgaları beraberinde farklı problemleri gün yüzüne çıkarmış ve 1980 sonrasında ABD’ye yasal olmayan göçlerin sayısında da büyük bir artış görülmesi toplam göç oranının hesaplanamaması sorununu da beraberinde getirmiştir. ABD içerisindeki resmi kurumların verileri kendi içerisinde farklılıklar barındırmasına rağmen 2000 yılından itibaren ABD'de yaklaşık olarak 8 milyon göçmenin yasal olmayan bir biçimde ülkede ikamet ettiği varsayılmaktadır (Singer, 2003).

Meydana gelen tüm bu göç hareketleri günümüzde ABD’yi kaçınılmaz bir biçimde en fazla kültürel çeşitlilik yapısına sahip ülke konumuna getirmiştir. ABD’nin sahip olduğu bu çeşitlilik yapısının anlaşılabilmesi için çeşitliliğin neden olduğu günümüz nüfus yapısı ve gelecekte bu nüfusun nasıl yeniden şekilleneceğine yönelik yapılan tahminlerin vurgulanması kritik önemdedir. Günümüzde ABD’nin 330 milyon nüfusu bulunmaktadır ve 2060 yılında ise bu nüfusun 400 milyona ulaşması beklenmektedir. Yapısal olarak incelendiğinde başta Beyaz Amerikanlar olmak üzere ülkenin yaş ortalaması büyük bir yükselme trendi içerisindedir. Çoğunluğu oluşturan Beyaz Amerikanların yaş ortalaması artma eğilimindeyken, azınlık olarak nitelendirilen grupların doğum oranlarının yükselme dinamiğine sahip olması 2060 yılına gelindiğinde Beyaz Amerikanlar ve azınlıklar arasındaki farkın önemli ölçüde kapanacağ1nı açıkça göstermektedir (Vespa ve diğerleri, 2018).

Statista tarafından yayımlanan 2019 verilerine göre Beyaz Amerikanlar tüm Amerikan toplumunun \%60'nı meydana getirmektedir. Beyaz Amerikanlardan hemen sonra sayısal olarak en büyük azınlık \%18 oranında Hispanik/Latinolardır. Sonrasında \%12 oranıyla Afro/Amerikanlar en büyük ikinci azınlık statüsünde bulunurken \%4'ü Asya kökenliler oluşturmaktadır. Sayısal açıdan ABD’deki en küçük azınlık grup Amerikan yerlileri (Kızılderililer) ve Alaska Yerlileridir. Amerikan ve Alaska yerlileri tüm Amerikanlar arasında \%0.7’lik dilimi oluşturmaktadır (Statista, 2019). 
Statista verilerine göre 2060 yılına gelindiğinde ABD'de kültürel çeşitliliğin daha keskin bir yapıy a bürüneceği ve özellikle Hispanik/Latinoların sayısal olarak Beyaz Amerikanlara büyük bir meydan okuma yaratacağı kesindir. Veriler günümüzde \%60 oranına sahip Beyaz Amerikanların 2060 y1lında \%43’e düşeceğini varsaymaktadır. Başta Meksika, Küba, Porto Riko ve diğer farklı Latin Amerika kökenli Hispanik/Latino nüfusunun \%29’a, Asyalıların ise \%9'a yükseleceğinin altını çizmektedir. Afro/Amerikanların sayısal oranında ise büyük bir değişim beklenmemektedir (Statista 2019). Tarihsel veriler incelendiğinde 20.yy'ın başında $A B D$ nüfusunun 7/8'ini Beyaz Amerikanlar oluştururken 1990 yılına gelindiğinde Beyaz Amerikanların oranı 1/5'e gerilemiştir. 2030 yılında bu oranının 1/4'e gerilemesi beklenmektedir (Vespa ve diğerleri, 2018). 1990 sonrası süreçte azınlıkların sayısal oranı metropol şehirlerde büyük bir yükselme trendi içerisine girmiş ve \%24'e yükselmiştir (Lee ve diğerleri, 2010). Eyalet düzeyinde ise ülkenin sahip olduğu çeşitlilik önemli bir farklılık göstermektedir. Günümüzde California ve Hawaii eyaletleri en fazla çeşitliliğe sahip iki eyaletken New York, Texas, Florida ve New Jersey eyaletleri çeşitliliğe en fazla sahip diğer eyaletlerdir. West Virginia ve New Hampshire ise çeşitlilik açısından en geride bulunan eyaletlerdir (Lee ve diğerleri, 2017: 1037).

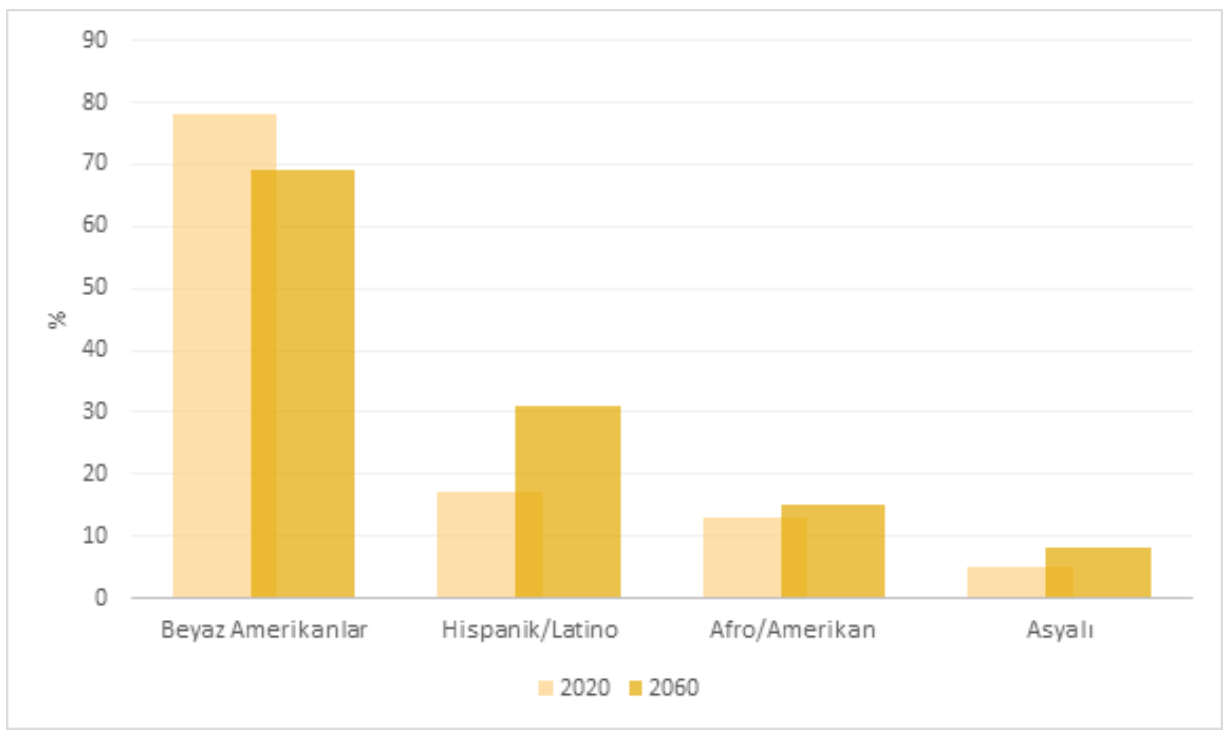

*U.S. Census Bureau verilerine göre Amerikan kültürel çeşitliliğinde nüfus oranlarının günümüz/gelecekteki yüzdelik dağılımı (2020 ve 2060) 


\section{Hispanik/Latino Kavramı ve Azınlığın Amerikan Toplumu İçerisindeki Rolü}

ABD toplumu içerisinde Hispanik/Latinoların konumunun tam olarak anlaş1labilmesi için Hispanik ve Latinoların etnik kökenlerinin tam olarak vurgulanması önemlidir. Literatürdeki çalışmaların birçoğu Latino ve Hispanik kelimelerini birbirlerinin yerine kullanmasına rağmen kendi içerisinde önemli farklılıklar bulunmaktadır. Hispaniklerin kökeni ana dili İspanyolca olan ülkelere ve etnik kökeni bu ülkelere bağlı olan bireylere dayanmaktadır. İspanya ve Latin Amerika kıtasında bulunan 19 ülke bu sınıfa dahil edilmektedir. Öte yandan Latinolar ise Latin Amerika ülkelerinden ABD'ye göç eden bireyler için kullanılmaktadır (Holladay, tarih yok: 2). Bazı farklı çalışmalar Latino kelimesinin kullanımına Latince konuşan ülkelerden gelen bireyler için başvurmaktadır. Bu doğrultuda İtalyan, Fransız, İspanyol ve Portekizliler ABD içerisinde Latino olarak tanımlanan gruba dahil edilmektedir. (Marrow, 2003: 432). Literatürde Hispanik/Latino kavramları ırk çerçevesinde de ele alınmaktadır. Bu doğrultuda ele alınan çalışmalar Hispanik/Latinoları kahverengi ya da çok ırklı olarak tanımlamaktadır (Marrow, 2003: 433-434). Genel bir görüş birliği bulunmamasına rağmen ABD içerisinde Hispanik/Latino Latin Amerika'dan gelen ortak tarih, kültür ve dile sahip olan insanlar için (Baia, tarih yok: 5) ya da Küba, Meksika ve Porto Riko gibi farklı coğrafyalardan gelen ve farklı kültürel, etnik ya da ulusal aidiyeti ve arka planı olan insanlar için kullanılmaktadır (Cruz, 1997: 159).

Önceki dönemlerde göç hareketleri kısmen başlamış olmasına rağmen Hispanik/Latinoların büyük oranda ABD’ye yerleşim süreci 20.yy başı itibariyle başlamıştır. Söz konusu göç hareketlerinde ise farklı motivasyonlar temel belirleyici olmuştur. Başta Latin Amerika ülkelerinin ciddi bir istikrarsızlık içerisinde olması ve bu durumu takiben beliren fakirlik, siyasi yozlaşma vb. durumlar göç motivasyonunu oluşturan temel faktörler olmuştur. Benzer bir şekilde bağımsızlığının ilk dönemlerinden itibaren ABD içerisinde yaşam koşullarının üst seviyede bulunması Hispanik/Latinoları ABD’ye çekme yönelimini arttırmıştır (Henderson, 2011: 8). 20.yy başlarındaki temel motivasyonlar günümüzde de sürekliliğini sağlamaya devam etmiştir. Bu durum günümüzde Hispanik/Latino sayısının bir taraftan oransal bazda artışına neden olurken diğer taraftan ABD'de azınlığa ait bireylerin büyük oranda kullandığ İspanyolcanın da ülke içerisinde kullanım alanını arttırmıştır. Özellikle sosyolojik boyutta bu durum Hispanik/Latinolar özelinde bir takım avantaj ve dezavantajları beraberinde getirmiştir (Gutierrez, 2017: 3). 2019 yılı verilerine göre ABD'de toplam nüfus içerisinde 59 milyon Hispanik/Latino grubu 
mevcutken toplam nüfusun ortalama olarak yüzde 17'sini oluşturmaktadır (Pew Research Center, 2019). ABD'de Kongre'nin sunduğu verilere göre 2060 yılından önce her üç kişiden birisinin Hispanik/Latino olması beklenmektedir (Joint Economic Comittee, 2015: 1). U.S. Census Bureau verilerine göre 2060 yılında Hispanik/Latino nüfusun toplamda 199 milyon olması beklenmektedir (U.S. Census Bureau, 2017).

Öte yandan, Hispanik/Latinolar da kendi içerisinde homojen bir yapıya sahip olmayıp önemli kültürel farklılıkları da içerisinde barındırmaktadır. Bu bağlamda ABD’nin 50 eyaleti ve eyalet statüsünde bulunmayan Washington olmak üzere ülkedeki tüm bölgelerde Hispanik/Latino nüfusu yaşamaktadır. Hispanik/ Latinolar içerisinde en hakim grup ise Meksika kökenli olup azınlığın yaklaşık 2/3’ünü oluşturmaktadır. Meksikalıların ardından sayıca en fazla grup Porto Rikolulardır. Tüm Hispanik/Latinolar içerisinde Porto Rikolular 1/10'luk bir orana tekabül etmektedir. Azınlığın diğer bileşenlerini ise Küba ve Salvadorlular oluşturmaktadır. Küba ve Salvadorlular \%4, Dominikliler \%3’nü meydana getirmektedir (Davilla, 2017: 2).

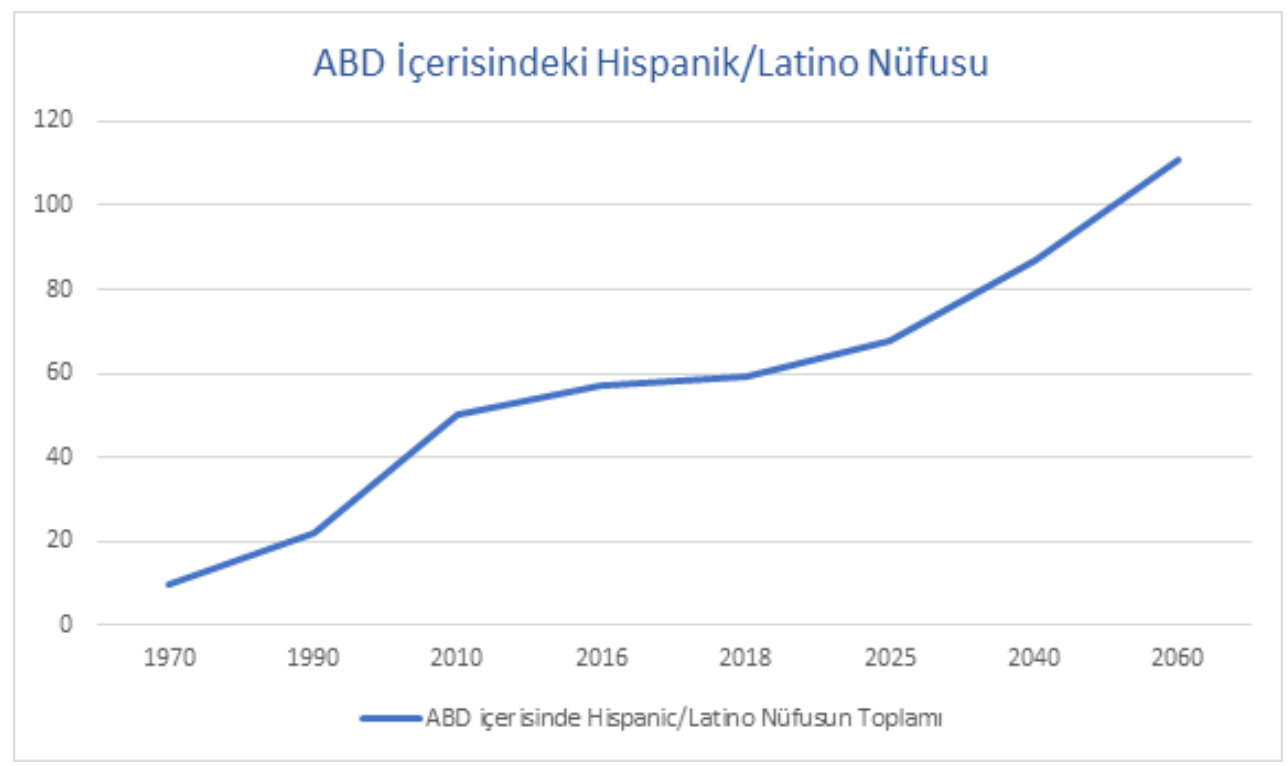

*Pew Research Center ve U.S. Census Bureau verilerine göre 1970-2060 yılları arasında Hispanik/Latino nüfus oranları

\section{ABD Iç̧erisinde Hispanik/Latino Coğrafi Yayılımı}

Ülkenin tüm bölgelerinde nüfusu bulunmasına rağmen Hispanik/Latinoların nüfus dağılımı ülke genelinde farklılık göstermektedir. Azınlığın ağırlıklı 
olarak yaşadığı bölge ise Güney Atlantik'tir. Florida, Texas, Piedmont ve California eyaletleri hem bulundukları coğrafi konum hem de sahip oldukları ekonomik avantajlar gereği azınlıkların en fazla bulunduğu noktalardır. Özellikle güney eyaletler Hispanik/Latinoları nüfusunu büyük oranda içerisinde barındırmasına rağmen kuzey eyaletlerde de önemli bir nüfus oranı bulunmakta ve ilerleyen dönemlerde gözle görülür bir artış beklenmektedir. Başta Washington ve West Colorado bölgelerinde Hispanik/Latino nüfus oranının hızlı artışı göze çarpmaktadır (Steven Martin, 2015: 4). Benzer bir şekilde Atlanta gibi Hispanik/Latino bireylerin oransal olarak düşük sayıda bulunduğu bölgelerde Beyaz Amerikanların nüfus artış oranının azalma eğilimi göstermesi Hispanik/Latinoların toplam nüfus oranının artmasını tetiklemektedir (Martin ve diğerleri: 2015: 5).

Amerikan Nüfus Sayım İdaresi güncel verilerine göre ise ABD’de Hispanik/Latino nüfusunun sayıca en hakim olduğu eyalet California'dır. Veriler California içerisinde toplamda 15 milyon Hispanik/Latino yaşadığını hesaplamıştır. Texas ise California'nın hemen ardından ikinci sırada yer almakta ve burada azınlığın 11 milyonluk bölümü yaşamaktadır. Toplam California, Texas ve Florida eyaletleri özelinde ise Hispanik/Latinolar toplam nüfusun yarısından fazlasını meydana getirmektedir (U.S. Census Bureau, 2017).

Yukarıda da değinildiği gibi azınlığın oransal düzlemde artış göstermesi ve ABD içerisinde İspanyolca dilinin kullanım dağılımı arasında sıkı bir korelasyon ilişkisi bulunmaktadır. İstatistikler 2016 yılında İspanyolca konuşan kişi sayısının 40 milyona eriştiğini hesaplamıştır. İspanyolcayı ana dili olarak kullanan bu grubun yaklaşık yarısı ise İngilizce konuşamamaktadır (U.S. Census Bureau, 2017).

\section{Amerikan Siyaseti ve Hispanik/Latinolar}

Tüm ülke içerisinde azınlık nüfusunun hızlı bir artış trendi içerisinde olması siyasi düzlemde temsil alanının büyük oranda artmasında ve Amerikan iç ve dış politika yapısının yeniden belirlenmesinde önemli bir etken olmuştur. Hispanik/Latinoların özellikle doğum oranının Beyaz Amerikanlardan fazla olması sonucu nüfus oranlarında yaş ortalamasının 18 yaş altı grubun ilerleyen dönemlerde siyaseti şekillendirici etkisi büyümekte ve siyasete aktif katılım oranını arttırmaktadır. Bir örnekle açıklanması gerekirse 8 yıllık süreçte (2004-2008) oy kullanım oranı \%3 artış göstermiştir. Aynı dönem içerisinde Beyaz Amerikanların oy oranlarında gerileme yaşanması ve 2012 yılında beyaz Amerikanların oy oranının yüzde 71'den yüzde 63'e gerilemesi Hispanik/Latinoların siyasi zeminde etkisinin daha fazla artmasina neden olmuştur. (Frey, 2016: 267-268). 
Siyasi katılım özelinde Hispanik/Latino azınlığının seçimlerde etkisinin en fazla arttığı dönem 2008 yılında yapılan ABD başkanlık seçimleri olmuştur. Verilerle ele alındığında ise Hispanik/Lationların tarihsel süreç içerisinde büyük oranda Demokrat Parti'ye oy verme eğiliminde olduğu açık bir şekilde görülmektedir. Özellikle 1960 yılı sonrasında ise Demokrat kesime olan bağlılığının artması ülke içerisindeki ara seçimler ve başkanlık seçimlerinde azınlığın belirleyici bir rol oynamasını beraberinde getirmiştir. Bilhassa 2008 yılında yapılan ABD başkanlık seçimlerinde Demokrat Parti'den siyahi bir aday olarak Barrack Obama'nın gösterilmesi azınlık statüsünün ülke seçimlerinde önemli bir etken olmasını beraberinde getirmiştir. 2008 ve 2012 başkanlık seçimlerinde Obama'nın başa gelmesinde Hispanik/Latino oy oranlarının önemli bir etkisi olduğu açıkça görülmektedir (Frey, 2016: 268-270).

Genel seçimlerin yanı sıra ülke içerisinde nüfus dağılımı farklılaşmasının bir getirisi olarak eyalet düzeyindeki seçimlerde azınlığın etkisi değişmektedir. Azınlığın özellikle batı ve güney eyaletlerinde çoğunlukla yaşamını sürdürmesi söz konusu eyaletlerin siyasi yapısı üzerindeki ağırlıklı etkisini belirlemektedir (Frey, 2016: 268-270). Bu minvalde özellikle Texas ve Arizona siyasetinin şekillenmesinde azınlık önemli rol oynamaktadır. Texas ve Arizona'nın Cumhuriyetçi eyaletler olmasına rağmen Hispanik/Latinoların oy verme eğiliminin artışta olması eyalet meclisi boyutunda son dönemlerde Demokrat Parti temsilcilerinin de koltuklarının artmasına olanak sağlamaktadır (Frey 2016, 271). Özellikle Meksika ve Porto Riko kökenlilerin Demokrat Parti'nin göçmenlere yönelik olumlu bakış açısından dolayı bu partiye olan yakınlığı göze çarpmaktadır (Ibarra, 2011: 11).

2016 yılında Cumhuriyetçi Parti'den Donald Trump'ın ABD başkanı seçilmesinin ardından ise Hispanik/Latinoların ülke içerisinde konumlarında önemli değişiklikler yaşanmıştır. Pew Research Center'ın 2018 yılındaki çalışmalarına göre grubun yaklaşık olarak yüzde 70'i Trump yönetimi politikalarının kendi siyasi, sosyal ve ekonomik yaşamlarını olumsuz bir şekilde etkilediğini ileri sürmüştür. Bu oran Obama yönetiminde yüzde 10’luk bir kısmı oluştururken Bush döneminde ise yüzde 41'lik bir alanı meydana getirmiştir. Benzer bir şekilde ABD'nin geleceği hakkında olumsuz fikre sahip Hispanik/ Latinoların oranlarında 2008 Ekonomik Krizi'nden bu yana en büyük artış Trump yönetiminde ortaya çıkmıştır (Lopez ve diğerleri, 2018: 1-25).

Hispanik/Latinoların, Trump yönetiminin politikalarından rahatsız olması ve politikaların ülkeye zarar verdiğini iddia etmeleri 2018 yılı ABD ara seçimlerinin sonuçlarına da önemli derecede yansımıştır. Özellikle geçmiş ara seçimlerle kıyaslandığında Hispanik/Latino grup bu seçimlere çok daha fazla 
katılım göstermiştir. Bu seçimler neticesinde elde edilen anket verilerine göre Hispanik/Latino grup ABD içerisinde Demokratlara bağlılığını daha fazla göstermiştir. Grubun yüzde 48'i Demokrat Parti'yi desteklediğini söylerken yüzde 14'ü Cumhuriyetçi Parti'yi desteklediğini belirtmiştir. Yüzde 32'lik kısım ise iki partinin politik yapılarında Hispanik/Latinolar üzerine etki edecek herhangi bir fark olmadığını iddia etmiştir (Lopez ve diğerleri, 2018: 44).

ABD'de Hispanik/Latino azınlık toplumunun büyük oranda Demokrat Parti'ye oy verme eğiliminde olduğu kabul görse de özellikle son dönemlerde Cumhuriyetçi Parti'ye desteğinde nispeten bir artış görülmektedir. 2016 seçimlerinde Donald Trump, başta göçmen konusu ve insan hakları özelinde farklı azınlıklardan büyük bir tepki toplamasına rağmen, Hispanik/Latino oylarının toplamda 1/3'ünü toplamayı başarabilmiştir. 2016 seçimleri Hispanik/Latinoların Cumhuriyetçi Parti’ye yönelik son dönem desteğini açık bir şekilde ortaya koysa da, literatürde konu üzerine araştırma yürüten kimi çalışmalar söz konusu oy oranının 1970'li yıllara dayandığını ileri sürmektedir. Konu özelinde en kapsamlı çalışmalardan birisini yürüten Gerolda Cadava, Cumhuriyetçi Hispanik/Latinolar üzerine yaptığı çalışmada 1972 yılı seçimlerinde Richard Nixon'un ABD başkanı seçilmesinden beri azınlığın 1/3-1/4 oranında Cumhuriyetçi Parti'ye oy verdiği bulgusuna ulaşmıştır.

Yukarıda vurgulanan duruma benzer bir şekilde ABD tarihinde Hispanik/ Latinoların ülke seçimlerinde ilk başkan adayı Benjamin Fernandez de adaylığını Cumhuriyetçi Parti'den koymuştur. Cadava'nın görüşlerine benzer bir şekilde siyaset bilimci Stephen Nuno-Perez de genel görüşün aksine Hispanik/Latinoların daima Demokrat kökenli olmadığı, tersi bir şekilde, Cumhuriyetçilerle benzer görüş ve yaşam biçimleri olup buraya oy verme yöneliminin de yüksek olduğunu ileri sürmüştür (Reyes 2020). Hispanik/Latinoların Cumhuriyetçi Parti'ye asıl yönelimi ise California eyaleti özelinde başlamıştır. Özellikle Nixon ve Reagan yönetimlerinde Cumhuriyetçi Parti'ye başlayan yönelim 1990’lu yıllar boyunca da artarak devam etmiştir (Cadava, 2020).

Hispanik/Latino kökenlilerin son dönemlerde siyasi katılımlardaki artışı ABD'de bürokratik ve yönetim seviyesine yükselmelerinde de önemli bir rol oynamıştır. Ülkenin bağımsızlığından günümüze kadar geçen süreç içerisinde Hispanik/Latinolar dönemsel olarak özellikle Kongre'de önemli görevler alsa da özellikle 2008 sonrası dönemde Hispanik/Latino kökenli birçok senatör Kongre'de önemli görevler ve bakanlıklar üstlenmiştir. 2009 yılında ABD başkanı Barack Obama Supreme Court'a ilk defa Hispanik/Latino kökenli Sonia Sotomayor'u atamıştır (Ibarra, 2011: 2). Amerikan siyasetinde diğer önemli Hispanik/Latino kökenli isimlerse Marco Rubio ve Ted Cruz'dur. 
Hispanik/Latinoların Demokrat siyaset yöneliminin aksine her iki senatör de Cumhuriyetçi tarafta bulunmakta ve Texas ve Florida gibi iki büyük eyalette senatörlük görevlerini sürdürmektedirler. Cruz ve Rubio'nun siyasi anlamda en önemli etkileri ise 2016 Başkanlık seçimlerinde ortaya çıkmış ve her iki aday seçimler için parti içerisinden aday adayı olarak gösterilmiştir (Siddiqui ve Jacobs, 2016). Benzer bir şekilde her iki siyasetçi son dönemlerde Müeller Raporu'yla (Mueller Report) ilgili de aktif bir siyaset yürütmekte ve raporun halka arz edilmesi için baskı yapmaktadırlar (Miller, 2019).

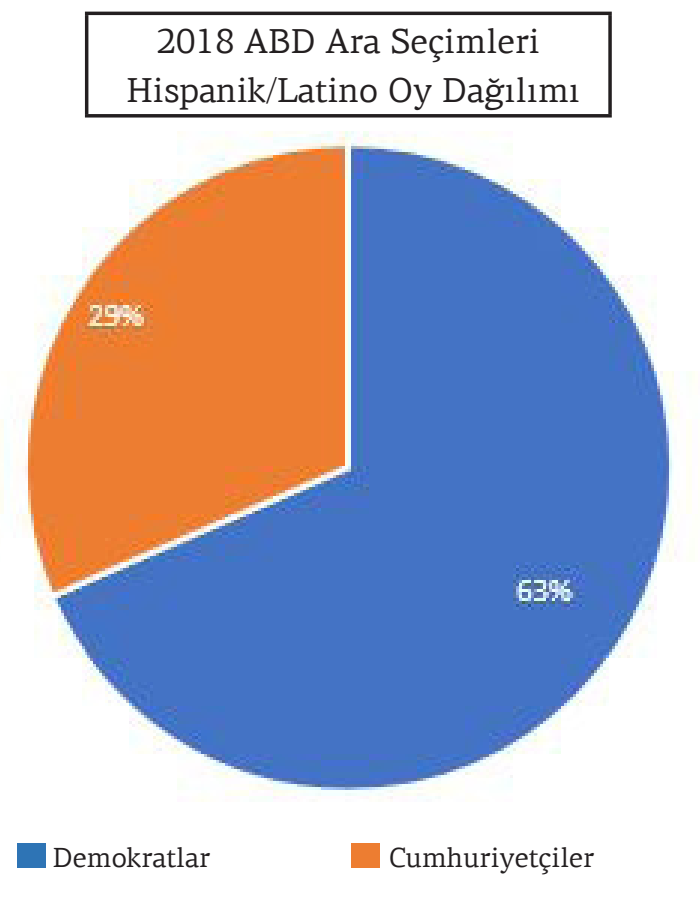

*Pew Research Center/ 2018 ABD Ara Seçim Hispanik/Latinoların Oy Dağılımı

\section{Hispanik/Latinoların Ekonomik Koşulları ve Amerikan Ekonomisi Üzerine Etkileri}

Hispanik/Latinolar nüfus oranlarının artmasının yanı sıra eğitim seviyelerinde görülen artışın grubun ülke ekonomisi içerisindeki katkısı ve gelir dağıllmı değişiminde de önemli bir etkisi olmuştur. Siyasi alandaki temsiliyet ve katılıma benzer bir şekilde son 20 yıllık dönem içerisinde Hispanik/Latinolar farklı iş alanlarına dahil olmuş ve farklı alanlardaki işgücü piyasasına önemli katkı sağlamıştır. Hispanik/Latinoların 2015 yılı içerisinde toplam alım gücü yaklaşık olarak 687 milyar dolara ulaşmıştır. Grup içerisindeki alım gücünün yıllar bazında artış göstermesi ülkeye ödenen verginin de önemli ölçüde 
artmasının önünü açmıştır. Bu bağlamda Hispanik/Latinoların federal düzeyde ABD’ye ödediği vergi yaklaşık olarak 139 milyar dolarken yerel ve eyalet düzeyinde ödenen vergi 76 milyar dolar olarak hesaplanmıştır. Alım gücü ve vergi açısından ülke ekonomisine grup tarafından gerçekleştirilen katkı önemli ölçüde artış göstermiştir (New American Economy, 2017: 9).

Hispanik/Latino grubun vergi özelinde ülkeye sağladığı ekonomik katkı özellikle belli eyaletlerde daha fazla ortaya çıkmaktadır. New Mexico eyaleti çerçevesinde ele alındığında ortalama olarak toplam verginin 1/3'ü Hispanik/Latino grubu tarafından verilmektedir. Bu oran New Mexico'da Hispanik/ Latinoları diğer gruplar arasında en fazla vergi veren grup arasına yerleştirmiştir. New Mexico'dakine benzer bir durum Texas için de geçerlidir. Son verilere göre Hispanik/Latino grup ortalama olarak 38 milyar dolarla Texas'taki ödenen toplam verginin yüzde 20'sinden fazlasını oluşturmaktadır. Texas ve New Mexico'nun ardından ödenen toplam verginin ortalama yüzde 17'siyle Florida, California ve Arizona'da da en fazla vergi veren gruplar arasinda yer almaktadır (New American Economy, 2017: 9).

Hispanik/Latinoların ABD ekonomisine diğer bir katkısı girişimcilik alanında ön plana çıkmaktadır. Nüfus oranı ve vergi ödemelerinin yanı sıra eğitim seviyelerindeki artışla bağlantılı bir şekilde son 10 yıllık dönemde Hispanik/Latino grubunun ekonomik anlamda farklı alanlardaki girişimcilik faaliyetleri önemli bir artış göstermiştir. 1990 ve 2012 yılı arasındaki verilere göre Hispanik/Latino girişimcinin sayısı 3 kat artarak ortalama 570 binden 2 milyona yükselmiştir. 2015 yılındaki verilere göre ABD’de her 7 girişimciden 1'i Hispanik/Latino grubundandır. Yine aynı yılın verileri Hispanik/ Latino grubun girişimcilik üzerinden 27 milyar dolarlık gelir elde ettiğini göstermektedir (New American Economy 2017, 13-14). Hispanik/Latino grubun girişimcilik alanında bölgesel düzeyde en fazla katkı yaptığı iki eyalet olarak yeniden Texas ve California öne çıkmaktadır. Bu bağlamda toplamda Texas'ta 580bin ve California'da ise 400bin kadar Hispanik/Latino girişimci bulunmaktadır. Bütün olarak bakıldığında ise ABD içerisindeki tüm eyaletlerin yarısında 10bin Hispanik/Latino girişimci bulunmaktadır (New American Economy, 2017: 17).

U.S. Census Bureau'nun verilerine göre Hispanik/Latino grubun girişimcilik neticesinde kurdukları şirketlerin sayısı 2002 ve 2012 yılları arasında iki kat artış göstermiş ve bu şirketlerin sayısı 3 milyona ulaşmıştır. 2012 yılı içerisinde Hispanik/Latino inisiyatifiyle oluşturulmuş şirket sayısı ABD'deki toplam şirket oranının yüzde 12'sini oluşturmuştur. Sözü geçen girişimcilik oranı ülke içerisindeki diğer azınlıklarla kıyaslandığında da önde bulunmaktadır. 
2002 yılı itibariyle Hispanik/Latinolar ülke içerisindeki tüm azınlıklar arasında en önde olan konumunu sürdürmektedir (Eisnach, 2016: 33-35).

Hispanik/Latino grubun ekonomi alanındaki diğer rolü istihdamda öne çıkmaktadır. İstihdam alanında diğer tüm azınlıklar arasında Hispanik/Latino grubun çoğunluğu ülke içinde daha görünür duruma evrilmiştir. Grubun ABD işgücüne katkısı ve toplam istihdamı kendi içerisinde yüzde 80'in üzerine ulaşmıştır (Brick ve diğerleri, 2011: 11). İstihdam oranlarının ilerleyen dönemlerde de önemli ölçüde artacağı tahmin edilmektedir. 2034 yılından önce Hispanik/Latinoların istihdam oranının toplamda 40 milyon kişiye ulaşması beklenirken söz konusu artışın oranı ABD'nin toplam istihdam oranının tek başına çeyreğini oluşturacağı düşünülmektedir (Eisnach, 2016: 29). Hispanik/Latino grubun ABD'de işgücü alanına büyük bir katkısı olmasına rağmen daha fazla ulaşım ve inşaat gibi düşük gelirli iş grubunda çalıştıkları görülmektedir (Brick ve diğerleri, 2011: 12). 2016 yllı itibariyle ise 2008 yılında meydana gelen küresel ekonomik krizden beri Hispanik/Latino grubun işsizlik oranı yüzde 5.8'le en alt seviyeye inmiştir. Buna rağmen Hispanik/Latino gruba dahil olan diğer alt gruplarda bu durum farklılık göstermektedir.

Hispanik/Latinoların son 20 yıllık dönemde olduğu gibi ilerleyen dönemlerde de $A B D$ ekonomisine büyük ölçüde katkı sağlanacağı beklenmektedir. Bu bağlamda yalnızca niceliksel değil niteliksel katkılarla da ön plana çıkan Hispanik/Latinoların ilerleyen dönemlerde özellikle banka, sigorta ve diğer finansal kuruluşlara daha fazla katılım sağlaması beklenmektedir. Hispanik/ Latinoların ülke içerisinde farklı işgücüne toplam katkının Amerikan GSYİH’na toplamda yüzde 0.21'lik bir katkı sağlayacağı hesaplanmaktadır (Valladares, 2019).

Hispanik/Latino grup içerisinde istihdam ve girişimciliğin artması fakirlik oranının da son dönemlerde azalmasını beraberinde getirmiştir. İstihdamın yanı sıra ABD ekonomisinin gelişme eğiliminde bulunması da fakirlik oranının gerileme göstermesi de önemli bir etken olmuştur. 2016 yllı verilerine göre ABD'de fakirlik oranı yüzde 13.5'ten yüzde 12.7'ye gerilemiştir. $\mathrm{ABD}$ içerisindeki söz konusu bu durum Hispanik/Latino grup içerisinde fakirlik oranının yüzde 21'den yüzde 19'a düşmesine olanak sağlamıştır. Sözü geçen oranlarla birlikte Hispanik/Latino grup içerisinde fakirlik sınırı altında yaşayan kişi sayısı 12 milyondan 11 milyona gerilemiştir (Semega ve diğerleri, 2017: 12). 2016 verilerine göre Hispanik/Latino grubun ylllık ortalama geliri 47 bin dolara ulaşmıştır. Hispanik/Latino grubun ekonomik gelişiminin bu şekilde ilerleme kaydetmesi sağlık koşullarına erişimi de arttırmıştır. Söz 
konusu yılın verilerine göre sağlık sorunlarına erişimde sıkıntı yaşayan Hispanik/Latino grubun oranı yüzde 16'ya gerilemiştir (U.S. Census Bureu, 2017).

Hispanik/Latino grubun son dönemlerde ABD’deki işgücüne katkısı iki temel nedenden dolayı artış göstermektedir. Bunlardan birincisi Hispanik/Latino grubun $\mathrm{ABD}$ içerisinde hızla artmakta olan nüfus oranıyken bir diğeri ise Hispanik/Latino grubunun diğer gruplarla kıyaslandığında işgücüne katılıma daha eğilimli olmasıdır. ABD içerisinde işgücü piyasası katılımı üzerine bir kıyaslama yapıldığında Hispanik/Latino grubun yüzde 65 ortalamayla özellikle beyaz Amerikanlar'ın yüzde 62'lik oranını geride bırakmaktadır (Eisnach, 2016: 26). Bu bağlamda Hispanik/Latino grubun yüzde 67'si inşaat ya da doğal kaynak temelli işgücü piyasasına dahilken yüzde 20'lik bölümü ise işletme, bilim ya da sanat alanlarına katılım göstermiştir (U.S. Census Bureau, 2017).

Hispanik/Latino grubun 2011 ve 2015 yılları arasında ABD işgücü piyasasına katkısı önceki dönemlerle kıyaslandığında daha fazla artış göstermektedir. Söz konusu dönem aralığında Hispanik/Latino işgücü piyasasına katkı ortalama 4 milyon kişi artış göstermiş ve bu dönem aralığında toplam ABD işgücü piyasasının ortalama yüzde 17'sine ulaşmıştır. ABD içinde farklı analizler son dönemlerde artan Hispanik/Latino grubun son dönemlerde olduğu gibi gelecekte ekonomik katkıya devam edeceği üzerinde durmaktadır. Bunun en önemli nedenleri arasında ise yukarıda da vurgulandığı gibi Hispanik/Latino olmayan grupların nüfuslarının yaşlanma eğilimindeyken Hispanik/Latino grubun görece daha genç bir yapıya sahip olmasıdır. Hispanik/Latino grubun yakın gelecekte ABD ekonomisine katkısı üzerine yayımlanan bir raporda 2034 yılına kadar 41 milyona ulaşacağı tahmin edilirken toplamda tüm işgücünün çeyreğini meydana getireceği düşünülmektedir (Eisnach, 2016: 27).

\section{Hispanik/Latinolar ve Eğitim}

ABD'de Hispanik/Latino grubun ülke ekonomisine katkısının yanı sıra siyasi alandaki katılımının ve temsiliyetinin artması grubun eğitim seviyesinin son dönemlerde artış göstermesiyle de yakından ilgili olmuştur. 2016 yılı verilerine göre Hispanik/Latino grubun toplamda yüzde 67'si en az lise diplomasına ve 15'i de üniversite lisans, yüksek lisans veya doktora diplomasına sahip olmuştur. Bu oranlar neticesinde toplamda 5 milyon kişi üniversite lisans diplomasına sahipken 1.5 milyon yüksek lisans veya doktora seviyesine ulaşmıştır (U.S. Census Bureau, 2017). 2000 ve 2015 yılları arasında Hispanik/Latino lise mezuniyet oranı ise yüzde 22'den yüzde 37'ye yükselmiştir (Field, 2018). 
Son 10 yıllık süreç içerisinde Hispanik/Latinoların eğitim düzeyindeki en önemli gösterge liseden ayrılma oranlarındaki düşüşte ortaya çıkmaktadır. 2000 yılında yüzde 32 olan Hispanik/Latinoların liseden ayrılma oranları 2014 yılında yüzde 12’ye gerilemiştir. Bu durumla birlikte Hispanik/Latinoların diğer etnik gruplarla kıyaslandığında liseyi terk etme oranları yine de daha yüksektir. Hispanik/Latinoların eğitim alanında üniversiteye kayıt oranlarında da önemli bir artış olmuştur. 1993 yılında iki ya da dört yıllık üniversitelere kayıt olan Hispanik/Latinoların oranı yüzde 22 iken 2014 yılında yüzde 32'ye yükselmiştir (Krogstad, 2016).

Hispanik/Latinolar son dönemlerde özellikle eğitim seviyesindeki artışa rağmen Beyaz Amerikanlarla kıyaslandığında daha az ücretle çalışmaktadır. ABD'de günümüzde lisans seviyesinde üniversite mezunu Hispanik/Latinolar yılık ortalama 50bin dolara çalışırken eşdeğer bir sektörde çalışan beyaz Amerikanlar yaklaşık 60bin dolar kazanmaktadır. Buna rağmen Hispanik/Latino yıllık geliri aynı eğitim seviyesine sahip Afro/Amerikanlarla karşılaştırıldığında daha fazladır (Fasules, 2017: 11-12). Az ücretle çalışmanın yanı sıra ayrıca Hispanik/Latinoların eğitim seviyesinde son dönemlerde bir artış olsa da ülke içerisinde diğer gruplarla kıyaslandığında geride bulunmaktadır (Fasules, 2017: 1). Günümüzde beyaz Amerikanların en üst konumda bulunduğu eğitim seviyelerinde Hispanik/Latinolar bu grubun yüzde 10 gerisinde bulunmaktadır (Field, 2018).

\section{Sonuç}

Çokkültürlülük günümüz toplum yapısında devletler için gerek politika yapımında gerekse çeşitli kültürlerin farklı alanlardaki temsiliyet alanları çerçevesinde en önemli olgulardan birisidir. Toplum içerisinde özellikle etnik, dini, rrksal ve dil temelinde şekillenen çokkültürlü yapı devlet politikalarının şekillenmesinde ve kültürel çeşitliliklerin bir arada yaşaması konusunda ortaya çıkan değişkenlerin de zeminini oluşturmaktadır. Bu çalışmada Amerikan çokkültürlülüğü ve söz konusu çokkültürlülük içerisinde Hispanik/Latinoların ülke içerisindeki konum ve koşulları ele alınmıştır. ABD, bağımsızlığından günümüze kadar geçen süreç içerisinde farklı coğrafyalardan aldığı göçler sonucu çokkültürlülüğün ve kültürel çeşitliliğin en fazla görüldüğü ülkelerden biri olmuştur. Günümüz Amerikan toplum yapısında çoğunluk olarak nitelendirilen Beyaz Amerikanların ülkenin nüfus oranı üzerinde hakim bir üstünlüğü bulunsa da ilerleyen dönemlerde ülke içerisindeki en büyük azınlık grup olan Hispanik/Latinoların özellikle genç nüfus yapısı ve hızla artmakta olan nüfusuyla önemli bir yer edineceği düşünülmektedir. 
Hispanik/Latino nüfusun ABD içerisinde artan etkisine bağlı olarak bu çalışmada, grubun ekonomik, siyasi ve eğitim koşulları analiz edilmiştir. Özellikle nüfus oranındaki artışla birlikte Hispanik/Latinoların tüm seviyelerde eğitime katılımlarının artması onların ülkenin ekonomik ve siyasi alanlara katılımını ve bu alanlardaki görünürlüğünün artmasını da beraberinde getirmiştir. Şüphesiz, Hispanik/Latinoların günümüzde Amerikan toplumu içerisindeki somutlaşan görünürlüğü en belirgin şekilde siyasi düzlemde kendisini göstermektedir. Özellikle, ABD Kongresi içerisinde gerek Temsilciler Meclisi gerekse Senato kanatlarında Hispanik/Latino temsilci sayısının gittikçe arttığı açıkça görülmektedir. Benzer bir şekilde, siyasi karar alım merciinin yanı sıra toplumsal alanda da siyaset ve sivil topluma katılım oranlarında önemli bir ivmelenme görülmektedir. Tüm bu koşullar azınlığın, ülkenin siyasi gündem ve yapısını doğrudan şekillendirebilmesinin de önünü açmaktadır.

Hispanik/Latinoların üniversite mezuniyet oranlarının artmasının yanı sıra eğitimi yarım bırakma oranlarının düşmesi, işgücü piyasasına katılımında niceliksel ve niteliksel olarak etki sahibi olabilmesinin önünü açmıştır. Günümüz Amerikan ekonomisinin gelişiminde Hispanik/Latinoların zaten büyük olan ve gittikçe büyümekte olan etkisi kabul görmüş bir gerçek olarak karşımıza çıkmaktadır. Ekonomik düzlemde devlet kurumlarıyla birlikte girişimcilik alanında önemli bir ilerleme kaydeden Hispanik/Latinoların, tüm ABD girişimcilik sektörü içerisinde yüzde 10'un üzerinde dağılım göstermesi özel sektörün hakim güç olduğu ülkede azınlığın ekonomik konumunu açıkça göstermektedir. Öyle ki, toplam işgücü piyasası oranlarının verileri de Hispanik/Latinoları, Beyaz Amerikanların önünde konumlandırmaktadır.

Çalışmanın ortaya koyduğu sonuç, Hispanik/Latinoların ABD içerisinde siyaset, eğitim ve ekonomi alanlarında önemli bir değişim yarattığını açıkça ortaya koymaktadır. Söz konusu değişimin, Amerikan toplumu içerisinde bilhassa orta ve uzun vadede daha radikal gelişmeler yaratacağı üzerine literatürde de hâkim bir görüş uzlaşısı bulunmaktadır. Vurgulanması gereken diğer bir önemli unsur ise bu çalışma Hispanik/Latinoların siyaset, eğitim ve ekonomi oranları etkisi üzerinde dursa da diğer farklı alanların da göz ardı edilmemesi kritik önemdedir. Bu doğrultuda özellikle Hispanik/Latinoların son dönemlerde $\mathrm{ABD}$ içerisinde kültür ve sanat alanlarında da rolünün somutlaştığı açık bir biçimde görülmektedir. Başta edebiyat, müzik ve sinema bu alanların başını çekmektedir. Tüm bu bulgular Hispanik/Latinoların halihazırda ülke içerisindeki artan rolünün ilerleyen dönemlere daha da belirginleşeceğini göstermektedir. 


\section{Kaynakça}

Baia, Larissa R. “Hispanic-Latino"- True Representation of an Emergining Idendity?"

Barrett A. Lee, John Iceland ve Gregory Sharp (2010), Racial and Ethnic Diversity Goes Local: Charting Change in American Communities Over Three Decades.

Brick, Kate, Challinor, A.E. ve Rosenblum, Marc R. (2011), Mexican and Central American Immigrants in the United States. Washington: Migration Policy Institute.

Bond, James E. (2002), “Multiculturalism: America’s Enduring Challanges” Seattle Journal for Social Justice,ss. 59-71.

Cadava, Geraldo (2020), Op-Ed: Is the Republican Party poised for a comeback with Latinos? , (E.T. 23 Temmuz, 2020).

Cazessus, Elena Vesselinov ve Matthew A. (2018), "Melting Pot”, Vincent Parillo (ed.), Encyclopedia of Social Problems, Sage Publications, ss.1-6.

Colombo, Enzo (2014), “Multiculturalism”, Sociopedia. isa, ss.1-17.

Cruz, Alicia Re (1997), "The Mexican-American Community in the United States." Larry L. Naylor (ed.), Cultural Diversity, Westpord: Greenwood, ss. 159-177.

Çolak, Yılmaz (2010), Türkiye'de Devletin Kimlik Krizi ve Çeşitlilik: Yeni-Osmanlıcı, İslamcı ve Kürtçü Meydan Okumalar, Ankara: Kadim Yayınları.

Davilla, Alberto ve Mora, Marie T. (2017), Employment Outcomes of the Four Largest Hispanic Groups: 2013-2016. American Society of Hispanic Economist.

Denhart, Matthew. America's Advantage: A Handbook on Immigration and Economic Growth. The Bush Institute, 2015.

Eisnach, Jeffrey A. (2016), Making America Rich Again: Latino Effect on Economic Growth, Insight in Economics.

Fasules, Megan L. ve Carnevale, Anthony P. (2017), Latino Education and Economic Progress, Georgetown University.

Field, Kelly (2018), More Hispanics are Going to College and Graduating, But Disparity Persist. Massachusetts: Salem University.

Frey, William H (2016), How America's Diversity Explosion is Changing the Political Landscape, Washington: Council of the State Government.

Gutierrez, Rosana Hernandez-Nieto ve C., Marcus (2017), Hispanic Map of the United States 2017. Instituto Cervantes.

Henderson, Timothy J. (2011), Beyond Borders: A History of Mexican Migration to the United States, West Sussex: Wiley-Blackwell.

Hirschman, Charles (2014), "Immigration to the United States: Recent Trends and Future Prospects" Malaysian Journal of Economic Studies, ss. 69-85.

Holladay, Neal. Working With Hispanics. Princeton: USDA.

Huntington, Samuel P. (2004), Who Are We? The Challanges to America's National Idendity, New York: Simon \& Schuster Paperbacks.

Ibarra, Jounne ve Casellas, Jason P. (2011), Changing Political Landscape for Latinos in America. AAHHE.

Joint Economic Comitte (2015), Economic State of the Latino Community in America, Washington: United States Congress- Joint Economic Comitte. 
Jonathan Vespa, David M. Amstrong ve Lauren Medina (2018), Demographic Turning Points for the United States: Population Projections for 2020 to 2060, Washington: U.S. Department of Commerce.

Kennedy, John F (1964), A Nation of Immigrants. Harper\&Row.

Krogstad, Jens Manuel (2016), www.pewresearch.org, https://www.pewresearch.org/fact-tank/2016/07/28/5-facts-about-latinos-and-education/ (E.T: 20 Mayıs 2020).

Kukathas, Chandran (1998), "Liberalism and Multiculturalism: The Politics of Indifference", Political Theory, ss.686-699.

Kymlicka, Will (1995), Multicultural Citizenship. Oxford: Oxford University Press.

Lee, Barrett A., Martin, Michael J.R., Matthews, Stephen A. ve Farrell, Chad R. (2017), "State-Level Changes in US Racial and Ethnic Diversity, 1980 to 2015: A Universal Trend?", Demographic Research, ss. 1031-1048.

Mahfouz, Safi Mahmoud (2013), “America's Melting Pot or the Salad Bowl: The Stage Immigrant's Dilemma”, Journal of Foreign Languages, Cultures \& Civilizations, ss. 1-17.

Mark Hugo Lopez, Ana Gonzalez-Barrera ve Jens Manuel Krogstad (2018), More Latinos Have Serios Concerns About Their Place in America Under Trump, Pew Research Center.

Marrow, Helen (2003), "To Be Or Not To Be (Hispanic or Latino)" Sage Publication, ss. 427464.

Martin, Steve, Astone, Nan Marie, Peters, H. Elizabeth, Pendall, Rolf, Nichols, Austin, Hildner, Kaitlin Franks ve Stolte, Allison (2015), Evolving Patterns in Diversity, Washington: Urban Institute.

Modood, Tariq (2007), Multiculturalism, Cambridge: Polity Press.

Modood, Tariq (2001), “Their Liberalism and Our Multiculturalism?”, British Journal of Politics and International Relations, ss. 245-257.

New American Economy (2017), How Hispanics Contribute to the U.S. Economy, New American Economy.

Orosco, José- Antonio (2016), TOPPLING the MELTING POT Immigration and Multiculturalism in American Pragmatism, Indiana: Indiana University Press.

Parekh, Bhikhu (2000), Rethinking Multiculturalism, London: MacMillan Press.

Passel, Jeffrey S. ve Fix, Michael (1994), Immigration and Immigrants, Washington: Urban Institute.

Rawls, John (1985), “Justice as Fairness" Philosophy and Public Affairs, ss. 223-251.

Raz, Joseph (1998), “Multiculturalism”, Ratio Juris, ss.193-205.

Reyes, Raul A. (2020), Hispanic Republicans? Yep, and they're here to stay, says author Geraldo Cadava,(E.T: 23 Temmuz 2020).

Semega, Jessica L., Fontenot Kayla R. ve Kolar, Melissa A. (2017), Income and Poverty in the United States: 2016, Washington: U.S. Census Bureu.

Singer, Audrey ve James M. (2003), Changing Faces: Immigrants and Diversity in the TwentyFirst Century, Brooking Institute.

Statista. Ethnicities in America: Population by ethnic groups 2015 and 2060. 2019. https:// www.statista.com/statistics/270272/percentage-of-us-population-by-ethnicities/ (E.T: 11 Nisan 2019). 
114 | Orhan Çifçi

Taylor, Charles (1994), "The Politics of Recognition”, Charles Taylor (ed.) Multiculturalism: Examining The Politics of Recognition içinde, yazan Charles Taylor, 25-75. New Jersey: Princeton University Press, ss. 25-75.

Tok, Nafiz (2005), “iki Liberal Kültürel Çoğulculuk Modeli: Müdahale Etmeme ve Ayrımcılık Yapmama”, Liberal Düşünce, ss.29-44.

U.S. Bureau of Labor Statics (2017), Hispanics in the United States: Celebrating National Hispanic Heritage Month, U.S. Bureau of Labor Statistics.

U.S. Census Bureau (2017) Hispanic Heritage Month 2017. Washington: U.S. Census Burue.

U.S. Census Bureau. QuickFacts- United States. tarih yok. (E.T: 4 Haziran 2020).

Valladares, Mayra Rodriguez (2019), www.Forbes.com. 11 Şubat 2019. https://www.forbes. com/sites/mayrarodriguezvalladares/2019/02/11/hispanics-not-trump-are-the-biggest-engine-of-u-s-economic-growth/\#7c2a91d86e5e (E.T. 20 Mayıs 2019).

Vialet, Joyce (1980), A Brief History of U.S. Immigratin Policy. Washington: Congressional Research Service. 